64. Nectarinia natalensis, Jard.

Benguela. The only specimen observed.

65. Nectarinia Jardinit, Verr.

Very abundant about Benguela, even in comparatively barren places, where, I have observed, they eat little insects, particularly small spiders.

66. Picus flaviscapus, Ill.

From Mossamedes, or Little Fish-Bay.

67. Merops erythropterus.

Benguela.

68. Merops hirundinaceus.

Benguela.

69. Merops eagyptius, F.

enguela. These birds have all a very graceful flight, circling leisurely in the air. This last is most abundant.

70. Alcedo cristata.

Abundant at the Bimbas (lagoons near Benguela).

\title{
4. Supplementary Notes to the Review of Vermetide.
} By O. A. L. Mörch, of Copenhagen.

As I see, from Mr. Carpenter's "Supplementary Report", that several points in my papers on Vermetide, in these 'Proceedings' for the years 1861 and 1862 , may be misunderstood, I feel myself called upon to make some further explanations.

The constancy of conchological characters is very different in different families. In some families, for instance, very small differences in the sculpture, the convexity of the whorls, and the height of the spire are very constant and of great importance. Thus among the Helices such differences are frequently supported by very notable and constant differences in the lingual dentition. In some genera the colours are exceedingly variable in one and the same species-for instance, in Meretrix, Oliva, Pecten, \&c.,-in others, again, very constant as a specific mark-for instance, in Conus, $\mathrm{Cy}$ prea, Natica, \&c. Prof. Troschel has thus lately proved that Natica hebrea (Martyn) and N. stercus muscarum (Chemn.†), chiefly distinguished by a somewhat different pattern of colour, and united into one species by several modern authors, have a notably

* Report of the British Association for the Advancement of Science for 1863, p. 536.

$\dagger=$ Natica adspersa (Mke.) and N. millepunctata (Linn.), both of which are from the Mediterranean. 
different lingual dentition. The same is the case with Tritonium undatum (L.) and the Arctic Tritonium gronlandicum (Ch.), which are chiefly distinguished by the different consistence of the testaceous matter, but vary in the size, shape, and sculpture of the shell in an analogous manner, as the following scheme will show:-

\section{Tritonium undatum, $\mathrm{L}$.}

2. Buccinum acuminatum, Brod.

3. ciliatum, auct. Brit.

4. - humphreysianum, Bennet.
1. Tritonium undulatum, Möll. $=$ Buccinum labradorense, Reeve.

2. A similar form is known from Greenland by five specimens.

3. Tritonium græenlandicum, $\mathrm{Ch}$.

4. - - humphreysianum, Möll.

The variation of the quasi-parasitical species, however, almost surpasses belief. One of the most striking instances is the Patella compressa (L.), which owes its remarkably compressed form to its habit of affixing itself to the stems of the large seaweeds of the Cape of Good Hope. When it drops from its place, and is received on a flat object, an expanded limb is added to the edge, of a somewhat coarser sculpture, and the uniform yellowish colour is changed to a whitish colour mottled with red spots, which proves clearly ' at this species is undoubtedly a form of Patella miniata, Born. Dr. Gray even mentions a specimen which is first a Patella miniata, then a $P$. compressa, and ultimately again a $P$. miniata. When the latter form becomes full-grown*, "caput infantis superans" + , it is the Patella rustica of Linnæus. These three forms are by several authors placed in three different genera. These facts prove clearly the necessity of comparing extensive series of specimens before new species are established. It was very difficult for me, when I wrote my papers on the Vermetida, to procure numerous specimens of all the species, as this family has been very much neglected by collectors. I have, however, been able to compare sufficiently large suites of one or two species of each genus. I have most completely described all the different varieties of age and growth of Vermetus conicus, Dill. (P. Z. S. 1861, p. 341). I have convinced myself, by numerous dissected specimens, that this species is first a Petaloconchus with internal laminæ, then a Bivonia (Carp.) with liræ on the columella, without laminæ, and finally an Aletes (Carp.) with suddenly dilated whorls and a nearly smooth columella. I have only found the young in the latter form of shells. Finding it useful, or even necessary, to have a nomenclature for these differences, I have used these now superfluous generic terms for that purpose, in the same manner as the term Cysticercus is generally used for a stage of Tania, or Zoëta for the young Crab.

I some time ago got a specimen of Fasciolaria princeps from Mazatlan, with several solitary specimens of Bivonia contorta (Carp.) attached, two of which, after making three or four whorls, suddenly enlarge the aperture of the tube to twice its diameter, and change the dark-brown strongly granulated surface to a pale-yellowish nearly

* Gray, Guide to the Systematic Distribution of Mollusca, p.175; and Sowerby, Genera, fig. 3, Patella.

$\uparrow$ Museum Ludovicæ Ulricæ, p. 694.

Proc. Zool. Soc.-1865, No. VII. 
smooth shell, with longitudinal reddish bands, exactly answering to Aletes centiquadrus (Val., Carp.).

M. Lacaze-Duthiers* has discovered that the female Vermetus deposits the egg-bags (which are very like those of Hipponyx and Calyptraa) in the last whorl, towards the aperture, where the eggs are hatched. It seems to me probable that the large aperture of the last whorl stands in connexion with this habit, as it otherwise would not be easily understood how the animal would be able to protrude the head in search of food. Still it must be remembered that some Vermeti, in a young state, close the aperture up with a convex septum, provided with a central slit + . This septum is, perhaps, analogous to the hybernaculum of the Helices, and indicates only some periodical rest in the growth.

I have never intended to introduce a tri- or poly-nomial nomenclature; but I believe it is necessary to name the different varieties, forms, and deviations, as well as the differences of sex and age. My nomenclature for the varieties, therefore, cannot properly be compared either with Klein's or Middendorf's generic nomenclature. " Falco islandicus, var. gronlandicus, young male in winter dress," is certainly, for instance, a very long name; but I cannot see any superfluous words. I have never named a variety with eight words, as Mr. Carpenter (who seems to have overlooked that he has confounded the appellations of two distinct varieties from two different localities) indicates (l. c. p. 558).

\section{Additions and Corrections.}

Siliquaria florina (Defr., Chenu) is, according to M. Deshayes, a Vermetus, in the aperture of which a fragment of Tenagodus is inserted. For the variety figured by Dr. Chenu, M. Deshayes proposes (Animaux sans Vertèbres du Bassin de Paris, ii. p. 246) the name Siliquaria millepeda, which is synonymous with Serpula cochlearia (Defr., Sow. Gen., where it is stated to be from the "calcaire grossière at Orglandes") .

Tenagodus australis $(\delta)$ is a distinct species, which I have named $T$. reentzii.

Tenagodus (Рухіромa) мӧвіг, n. sp.

T. volubilis, laxa, solidissima, crassa, lcevigata, nitidula, sordide alba, infime flavescens; rima in anfr. tribus primis (qui adsunt) clausa, in anfr. sequente foraminibus duobus oblongis geminis remotis, deinde aperta marginibus irregularibus; aperturam versus hians, marginibus acutis simplicibus. Apex tubi septo hemispherico clausus.

Diam. aperturæ circ. $7 \mathrm{~m}$.

* Annales des Sciences Naturelles, sér. 4, vol. xiii. p. 248. It is also stated that the female of Bivonia semisurrecta has the mantle deeply fissured; but, unfortunately, it was not seen before the shell was lost.

† Gray, Annals of N. H. 1851, viii. p. 479, t. 17 B. f. 4-6; and Sowerby, Genera, Serpula, f. 5 . 
Tirrebourres, Davila, Cat. Rais. 1767, t. iv. f. $e$ ?; Buonanni, Recreatio, t. 20. f. C (quoad formam).

Hab. — ? ad Manillam? (Mus. Hamburg.).

The lid of the true genus Tenagodus was unknown to me. I have now had an opportunity of examining a specimen of T. squamatus, Blv., from St. Thomas's, in Mr. A. H. Riise's coliection.

Operculum irregulare, incurvo-conicum; anfr. ciliis sat longis; area centralis pallide flava, sulco profunde circumscripta, segmentis radiantibus circiter 7 , centro obscuro latiusculo, puncto centrali albo; limbus angustus, nitidus, reflexus, marginatus.

Serpula costalis, Lam. Guérin (Iconographie du R. A. t. 1. f. 2), represents probably the typical specimen of Lamarck, and is thus the same species as Vermiculus contortus, Soldr.

Vermetus Contortus, $\beta$. Favosa, probably owes its remarkable sculpture to a Flustra, which it has copied, in the same manner as I have mentioned that a specimen of Vermetus cereus, Carp., has copied an Astrcea.

Vermetus Anellum, Mörch. As this species is always sinistral, it cannot be the young of Vermetus squamigerus, but is more likely to be a Spirorbis. The genus Strebloceras is quite unknown to me; the Haliotis on which it is found is perhaps only a variety of $H$. corrugata (Gray), from which it differs in being rounder, more convex, and in the pearly interior being whitish.

Bivonia subtriquetra (Mörch) is, according to original specimens in the collection of Mr. O. Semper, Vermetus articulatus, Bonelli (Sismondi, Synopsis, ed. 2. p. 27).

Thylacodes imbricatus, Dkr. This name is preoccupied by Sandberger; the species must therefore be named

Thylacodes adamsir, Mörch, Journ. de Conch. 1859, p. 359; Adams, Ann. \& Mag. of N. H. 1864, Feb., p. 141.

Siphonium, sp., Mrs. Gray, Figures of Moll. t. \& - f. $2-4$, p. 82.

From Japan, according to Mr. A. Adams; bvt not from Borneo.

Vermetus peronir, Rouss. (Chenu, Ill. t. 4. f. 6), is perhaps different from $\boldsymbol{V}$. peronii (Val., Voy. de la Venus).

Thylacodes melanostomus, Mörch, $\mathrm{n}$. $\mathrm{sp}$.

T. solitaria, spiralis, perforata, brunnea, crusta tenui (aliena) virescente, spiraliter lirulata, lirce plerumque alternatim minores; lira 4-5 validiores, subaquidistantes, nodulis oblongis remotis; lira incrementi minuta, appressa, regulariter approximate, hic illuc acutiuscula, in intersectionibus lirarum nodulo obsoleta. Apertura circularis, faucibus nigrescentibadiis, columella candida.

Diam. aperturæ cirs. $15 \mathrm{~m}$.

Hab. ad Zanzibar, in Murice angulifero Linn. affixum (Coll. O. Semper.) specimen unicum. 


\section{$2 \mathrm{BHL}$ Biodiversity Heritage Library}

1865. "Supplementary Notes on the Review of Vermetidae." Proceedings of the Zoological Society of London 1865, 96-99. https://doi.org/10.1111/j.1469-7998.1865.tb02314.x.

View This Item Online: https://www.biodiversitylibrary.org/item/90412

DOI: https://doi.org/10.1111/j.1469-7998.1865.tb02314.x

Permalink: https://www.biodiversitylibrary.org/partpdf/67103

\section{Holding Institution}

Natural History Museum Library, London

\section{Sponsored by}

Natural History Museum Library, London

\section{Copyright \& Reuse}

Copyright Status: Public domain. The BHL considers that this work is no longer under copyright protection.

This document was created from content at the Biodiversity Heritage Library, the world's largest open access digital library for biodiversity literature and archives. Visit BHL at https://www.biodiversitylibrary.org. 